\title{
Assessing Management of Nitrapyrin with Urea Ammonium Nitrate Fertilizer on Corn Yield and Soil Nitrogen in a Poorly-Drained Claypan Soil
}

\author{
H. Habibullah ${ }^{1}$, Kelly A. Nelson ${ }^{2}$ \& Peter P. Motavalli ${ }^{1}$ \\ ${ }^{1}$ School of Natural Resources, University of Missouri, Columbia, Missouri, USA \\ ${ }^{2}$ Division of Plant Sciences, University of Missouri, Novelty, Missouri, USA \\ Correspondence: Peter P. Motavalli, School of Natural Resources, University of Missouri, Columbia, Missouri \\ 65211, USA. Tel: 1-573-884-3212. E-mail: motavallip@missouri.edu
}

Received: August 17, 2017

Accepted: September 20, $2017 \quad$ Online Published: October 15, 2017

doi:10.5539/jas.v9n11p17

URL: https://doi.org/10.5539/jas.v9n11p17

\begin{abstract}
Use of nitrification inhibitors (NI) in agricultural production systems is considered a risk management strategy for both agricultural and environmental considerations. It can be utilized when risk of reduced nitrogen $(\mathrm{N})$ fertilizer use efficiency or yield, and risk of pollution from mineral $\mathrm{N}$ is high which can occur in poorly-drained soils that are vulnerable to waterlogging and runoff. Field research was conducted on corn (Zea mays L.) from 2012 to 2015 in Missouri, USA on a poorly-drained claypan soil. Treatments consisted of two application timings of urea ammonium nitrate (UAN) fertilizer solution [pre-emergence (PRE) and V3 growth stage], two application rates (143 and $168 \mathrm{~kg} \mathrm{~N} \mathrm{~h}^{-1}$ ) in the presence or absence of nitrapyrin, and a non-treated control. UAN at $143 \mathrm{~kg} \mathrm{ha}^{-1}$ with nitrapyrin at the V3 growth stage resulted in the highest yield $\left(8.6 \mathrm{Mg} \mathrm{ha}^{-1}\right)$. Similarly, pre-emergence application of UAN $168 \mathrm{~kg} \mathrm{ha}^{-1}$ with nitrapyrin resulted in greater yields $\left(7.7 \mathrm{Mg} \mathrm{ha}^{-1}\right)$. UAN application rates and timings affected soil $\mathrm{NO}_{3}-\mathrm{N}$ and $\mathrm{NH}_{4}-\mathrm{N}$ concentrations more than the presence or absence of nitrapyrin during the growing season. A side-dress application of a lower rate of UAN with nitrapyrin at V3 was effective in poorly-drained soils when risk of $\mathrm{N}$ losses during the growing season due to unfavorable precipitation events and other environmental variables was high. A pre-emergence application of UAN with nitrapyrin was also effective and it may eliminate the need for split-application of $\mathrm{N}$ fertilizer later in the season thereby reducing the workload on growers during the growing season.
\end{abstract}

Keywords: nitrification inhibitor, urea ammonium nitrate, grain yield, fertilizer application timing

\section{Introduction}

Careful selection of $\mathrm{N}$ fertilizer sources, application rates, and application timings are common strategies to better match the crops $\mathrm{N}$ demand with supply. Application of $\mathrm{N}$ fertilizer in the spring at the time of planting or soon after emergence of the crop is a common fertilization practice for corn production in the Midwestern U.S. (Randall \& Sawyer, 2008). Nitrification inhibitors (NI) are also sometimes combined with ammonium based N fertilizers, such as anhydrous ammonia (AA), urea or urea ammonium nitrate solution (UAN) to slow the conversion of ammonium to nitrate $\left(\mathrm{NO}_{3}{ }^{-}\right)$after fertilizer application. Substantial research has been conducted on the use of nitrapyrin with AA (Wolt, 2004). There is lack of research studies which have investigated the effects of a new formulation of nitrapyrin (Instinct II, Dow Agro Sciences, Indianapolis, IN) and UAN fertilizer solution on soil $\mathrm{N}$, corn $\mathrm{N}$ status, and grain yield. Research has reported a 29 to $50 \%$ reduction in soil $\mathrm{NO}_{3}-\mathrm{N}$ loss when UAN was combined with a urease inhibitor and a NI (Halvorson et al., 2010; Halvorson \& del Grosso, 2012). However, few studies have reported significant increases in grain yields. One exception was Maharjan et al. (2017) who observed grain yield increases with application of UAN and nitrapyrin only in one out of two years when rainfall was relatively lower. The NI might not have had significant effects on yields in those studies since they were conducted with irrigated systems and NI typically works best in soils that experience saturated conditions.

In row-crop agriculture, synthetic fertilizers, such as urea, UAN, ammonium nitrate $\left(\mathrm{NH}_{4} \mathrm{NO}_{3}\right)$, AA and ammonium sulfate $\left(\left(\mathrm{NH}_{4}\right)_{2} \mathrm{SO}_{4}\right)$, are commonly used (Millar et al., 2010). As a $\mathrm{N}$ fertilizer source, UAN comes in a liquid form which makes it convenient for application and mixing with other nutrients or chemicals. Half of 
the $\mathrm{N}$ in UAN is in the urea form while the other half consists of ammonium nitrate which contains $\mathrm{NH}_{4}{ }^{+}$and $\mathrm{NO}_{3}{ }^{-}$forms at $25 \%$ each. Research is limited on use of UAN combined with nitrification inhibitors. One study, conducted over two years in Indiana, compared UAN application rates $\left(0,90\right.$ and $\left.180 \mathrm{~kg} \mathrm{~N}^{-1}\right)$, application timing (preemergence and sidedress at the V6 stage of corn growth) and use of nitrapyrin on corn yield, soil $\mathrm{N}_{2} \mathrm{O}$ emissions and yield-scaled $\mathrm{N}_{2} \mathrm{O}$ emissions (Burzaco et al., 2013). There was a $3 \mathrm{Mg} \mathrm{ha}^{-1}$ increase in yield when UAN was applied as a sidedress application with nitrapyrin at $180 \mathrm{~kg} \mathrm{~N} \mathrm{ha}^{-1}$ compared to a preemergence application without nitrapyrin at $90 \mathrm{~kg} \mathrm{~N} \mathrm{ha}^{-1}$. Although nitrapyrin significantly reduced both daily and cumulative soil $\mathrm{N}_{2} \mathrm{O}$ emissions when averaged across both years, UAN rate was the primary factor influencing corn yield, yield-scaled $\mathrm{N}_{2} \mathrm{O}$ emissions, soil $\mathrm{N}_{2} \mathrm{O}$ fluxes and cumulative soil $\mathrm{N}_{2} \mathrm{O}$ emissions followed by $\mathrm{N}$ application timing and nitrapyrin.

The objective of this study was to determine the effects of applying a NI in a poorly-drained claypan soil on soil $\mathrm{N}$, plant $\mathrm{N}$ status, and corn grain yield for different UAN application rates and application timings in the presence or absence of nitrapyrin.

\section{Method}

\subsection{Site Location and Experimental Design}

This research was conducted from 2012 to 2015 at the University of Missouri's Greenley Memorial Research Center $\left(40^{\circ} 1^{\prime} 17^{\prime \prime} \mathrm{N}, 92^{\circ} 11^{\prime} 24.9^{\prime \prime} \mathrm{W}\right)$ near Novelty, Missouri, USA. The soil is a Putnam silt loam (fine, smectitic, mesic Vertic Albaqualfs). This soil is characterized by the presence of a poorly-drained claypan subsoil at a depth of 20 to $40 \mathrm{~cm}$ from the surface (Anderson et al., 1990; Jung et al., 2006; Myers et al., 2007). This claypan layer has a $100 \%$ higher clay content than the above horizon. The depth to the claypan at this particular location ranges from 46 to $60 \mathrm{~cm}$ (data not presented).

The field site for each growing season was different from the previous year and all sites had been in corn-soybean (Glycine max L.) rotation. Soybean residues on the surface of the soil were not disturbed and field sites in all years were no-till. Field sites had a slope less than one percent and plot size was 3 by $15 \mathrm{~m}$. The experiment was arranged as a randomized complete block design (RCBD) with five replications. Treatments consisted of a factorial arrangement of two application timings of UAN fertilizer solution [pre-emergence (PRE) and V3 growth stage], two application rates (143 and $\left.168 \mathrm{~kg} \mathrm{~N} \mathrm{ha}^{-1}\right)$, and the presence or absence of nitrapyrin (0 or $0.513 \mathrm{~kg}$ a.i. $\mathrm{ha}^{-1}$ as Instinct (DowAgroSciences, Indianapolis, IN)). A non-treated control was included. Both the PRE and V3 applications were surface dribble-banded between corn rows using a $\mathrm{CO}_{2}$ propelled hand boom.

The corn hybrids planted each year were DKC62-97 in 2012, 2013 and 2014, and DK62-08 in 2015 in $76 \mathrm{~cm}$ wide rows. Seeding rate was 79,000 seeds ha ${ }^{-1}$ in 2012 and 82,000 seeds ha ${ }^{-1}$ in 2013, 2014 and 2015. Field operation timeline, maintenance fertilizer, and initial soil properties are reported in Table 1. Crop protection chemical applications are listed in Table 2. Chlorophyll (SPAD) meter leaf readings (Minolta SPAD-502, Konica Minolta Optics, Inc., Tokyo, Japan) were recorded for 10 plants per plot at V8 and VT growth stages (Ritchie et al., 1992). Corn grain yields were determined with a small-plot two row combine (Wintersteiger Inc., Salt Lake City, UT) and adjusted to $155 \mathrm{~g} \mathrm{~kg}^{-1}$ moisture content before statistical analysis. Additional corn response measurements included harvested plant population, grain protein concentration (Foss Intratec 1241, Eden Prairie, $\mathrm{MN}$ ), grain oil concentration, grain starch concentration, test weight and grain moisture content. The duration of the growing season in 2012, 2013, 2014 and 2015 was 144, 136, 182 and 148 days, respectively.

\subsection{Soil Sampling and Analytical Procedures}

Each year, soil sampling occurred prior to planting at each site using a stainless steel push probe from depth increments of 0 to $22 \mathrm{~cm}$ and 23 to $46 \mathrm{~cm}$ to characterize selected initial soil properties (Table 1). Standard soil test analytical methods were used by the University of Missouri Soil and Plant Testing Lab to analyze these samples (Nathan et al., 2006). Additional soil samples were collected from 0 to 22 and 23 to $46 \mathrm{~cm}$ depths at V3 and V7 corn growth stages during the season, as well as at harvest to determine soil $\mathrm{NH}_{4}{ }^{-} \mathrm{N}^{-}$and $\mathrm{NO}_{3}{ }^{-} \mathrm{-N}$ concentrations. All soil samples were air-dried, ground in a hammer mill and passed through a stainless steel sieve with $2 \mathrm{~mm}$ openings. Soil $\mathrm{NH}_{4}{ }^{+}$and $\mathrm{NO}_{3}{ }^{-}$were extracted using a $2 \mathrm{M} \mathrm{KCl}$ solution and analysis conducted using a Lachat QuikChem automated ion analyzer (Hach Corp., Loveland, CO).

\subsection{Climate Information}

Daily precipitation and air temperature data for each growing season were collected from an automated weather station maintained by the University of Missouri at the Greenley Memorial Research Center. Historical weather data from the same weather station were obtained from the Missouri Historical Agricultural Weather Database 
website (University of Missouri Extension, 2016) to calculate the average cumulative precipitation from 2001 to 2011.

\subsection{Statistical Analysis}

All statistical analyses were conducted using the SAS statistical program (SAS Institute, 2013). Initially, a single-factor ANOVA was performed to assess any significant difference between the non-treated control and N treatments. This was followed by a three-factor ANOVA to investigate any significant main effects and interactions. If the overall F was significant, Fisher's Protected Least Significant Difference (LSD) at $\mathrm{P} \leq 0.10$ was used for mean separation.

Table 1. Experimental timeline, initial soil properties from 0 to $22 \mathrm{~cm}$ and 23 to $46 \mathrm{~cm}$ depth, and maintenance fertilizer details from 2012 to 2015

\begin{tabular}{|c|c|c|c|c|}
\hline & 2012 & 2013 & 2014 & 2015 \\
\hline \multicolumn{5}{|l|}{ Timeline } \\
\hline Initial soil sample & 28 Mar. & 1 May & 9 Apr. & 22 Apr. \\
\hline Planting & 2 Apr. & 14 May & 9 Apr. & 22 Apr. \\
\hline PRE-treatment application & 2 Apr. & 14 May & 9 Apr. & 22 Apr. \\
\hline V3-soil sample ${ }^{\dagger}$ & 15 May & 5 Jun. & 12 May & 18 May \\
\hline V3-treatment application & 15 May & 5 Jun. & 12 May & 18 May \\
\hline V7-soil sample & 18 Jun. & 8 Jul. & 23 Jun. & 29 Jun. \\
\hline V8-SPAD reading & 13 Jun. & 8 Jul. & 23 Jun. & 29 Jun. \\
\hline VT-SPAD reading & $27 \mathrm{Jul}$. & 29 Jul. & $2 \mathrm{Jul}$. & 15 Jul. \\
\hline Plant population & 9 Jul. & 8 Aug. & $1 \mathrm{Jul}$. & $1 \mathrm{Jul}$. \\
\hline Harvest & 23 Aug. & 26 Sep. & 7 Oct. & 16 Sep. \\
\hline Harvest soil sample & 5 Sep. & 26 Sep. & 20 Oct. & 29 Oct. \\
\hline \multicolumn{5}{|l|}{ Initial Soil Properties } \\
\hline $\mathrm{pH}$ & 5.9 & 5.7 & 6.4 & 6.3 \\
\hline Neutralizable acidity (NA), $\mathrm{cmol}_{\mathrm{c}} \mathrm{kg}^{-1}$ & 1.7 & 3.5 & 0.8 & 0.9 \\
\hline Organic matter $(\mathrm{OM}), \%$ & 3.3 & 2.1 & 2.4 & 2.3 \\
\hline Bray 1 phosphorus (P), $\mathrm{kg} \mathrm{ha}^{-1}$ & 30 & 37 & 26 & 53 \\
\hline Calcium (Ca), $\mathrm{kg} \mathrm{ha}^{-1}$ & 4,822 & 3,624 & 3,873 & 5,049 \\
\hline Magnesium $(\mathrm{Mg}), \mathrm{kg} \mathrm{ha}^{-1}$ & 584 & 305 & 361 & 580 \\
\hline Potassium $(\mathrm{K}), \mathrm{kg} \mathrm{ha}^{-1}$ & 228 & 182 & 155 & 293 \\
\hline Cation exchange capacity (CEC), $\mathrm{cmol}_{\mathrm{c}} \mathrm{kg}^{-1}$ & 14.9 & 12.9 & 11.0 & 14.7 \\
\hline Nitrate-nitrogen $\left(\mathrm{NO}_{3}-\mathrm{N}\right), \mathrm{mg} \mathrm{kg}^{-1}$ & 6.6 & 13.1 & 9.2 & 8.0 \\
\hline Ammonium-nitrogen $\left(\mathrm{NH}_{4}-\mathrm{N}\right), \mathrm{mg} \mathrm{kg}^{-1}$ & 4.0 & 6.8 & 2.4 & 2.4 \\
\hline $\mathrm{pH}$ & 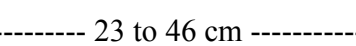 & 5.1 & 5.5 & 5.2 \\
\hline Neutralizable acidity (NA), $\mathrm{cmol}_{\mathrm{c}} \mathrm{kg}^{-1}$ & NA & 5.4 & 2.9 & 4.9 \\
\hline Organic matter $(\mathrm{OM}), \%$ & NA & 2.0 & 1.7 & 2.2 \\
\hline Bray 1 phosphorus $(\mathrm{P}), \mathrm{kg} \mathrm{ha}^{-1}$ & NA & 20 & 13 & 13 \\
\hline Calcium $(\mathrm{Ca}), \mathrm{kg} \mathrm{ha}^{-1}$ & NA & 3,283 & 3,578 & 4,941 \\
\hline Magnesium $(\mathrm{Mg}), \mathrm{kg} \mathrm{ha}^{-1}$ & NA & 293 & 407 & 874 \\
\hline Potassium (K), $\mathrm{kg} \mathrm{ha}^{-1}$ & NA & 114 & 103 & 137 \\
\hline Cation exchange capacity (CEC), $\mathrm{cmol}_{\mathrm{c}} \mathrm{kg}^{-1}$ & NA & 15.0 & 13.7 & 21.1 \\
\hline Nitrate-nitrogen $\left(\mathrm{NO}_{3}-\mathrm{N}\right), \mathrm{mg} \mathrm{kg}^{-1}$ & 4.3 & 4.9 & 6.4 & 3.4 \\
\hline Ammonium-nitrogen $\left(\mathrm{NH}_{4}-\mathrm{N}\right), \mathrm{mg} \mathrm{kg}^{-1}$ & 4.1 & 7.1 & 4.1 & 3.6 \\
\hline \multicolumn{5}{|l|}{ Maintenance Fertilizer } \\
\hline Fertilizer type & N-P-K & $\mathrm{NA}^{\S}$ & N-P-K-S-Zn & NA \\
\hline Application rate, $\mathrm{kg} \mathrm{ha}^{-1}$ & $19-90-134$ & NA & $22-90-157-22-2$ & NA \\
\hline Application date & 12 Apr. & NA & NA & NA \\
\hline
\end{tabular}

$\overline{\text { Note } .}{ }^{\dagger}$ Corn growth development stages (Ritchie et al., 1992); ${ }^{\ddagger} \mathrm{NA}=$ Not available. Data were only collected from 23 to $46 \mathrm{~cm}$ depth for $\mathrm{NO}_{3}-\mathrm{N}$ and $\mathrm{NH}_{4}-\mathrm{N}$ for $2012 ;{ }^{\S}$ Maintenance fertilizer was not applied in 2013 and 2015. 
Table 2. Plant protection chemical application timings, rates and date from 2012 to 2015

\begin{tabular}{|c|c|c|c|c|}
\hline Year & Herbicide common name & Timing & Rate (kg a.i. ha $\left.{ }^{-1}\right)$ & Date \\
\hline \multicolumn{5}{|l|}{2012} \\
\hline & Simazine $^{\dagger}$ & Fall applied & 1.12 & 3 Oct. 2011 \\
\hline & Glyphosate & & 0.43 & \\
\hline & Ace. + Flu. + Clo $^{\S}$ & Post application 1 & 1.19 & $2 \mathrm{Apr}$ \\
\hline & Glyphosate & & 1.26 & \\
\hline & Glyphosate & Post application 2 & 0.43 & 5 Jun \\
\hline & Mesotrione & & 0.11 & \\
\hline \multicolumn{5}{|l|}{2013} \\
\hline & Simazine & Fall applied & 1.12 & 28 Nov .2012 \\
\hline & Acetolchlor & Post application 1 & 1.61 & 14 May \\
\hline & Atrazine $^{\#}$ & & 2.25 & \\
\hline & Glyphosate & Post application 2 & 0.43 & 22 May \\
\hline & Mesotrione & & 0.11 & \\
\hline & Lambda-cyhalothrin $^{\dagger \dagger}$ & & 0.04 & \\
\hline \multicolumn{5}{|l|}{2014} \\
\hline & Acetochlor + Atrazine & Post application 1 & 3.97 & 6 May \\
\hline & Atrazine & & 0.56 & \\
\hline & Glyphosate & & 0.87 & \\
\hline & Glyphosate & Post application 2 & 0.87 & 11 Jun \\
\hline & Topramezone ${ }^{\star t}$ & & 0.012 & \\
\hline & Atrazine & & 0.28 & \\
\hline \multicolumn{5}{|l|}{2015} \\
\hline & Saflufenacil ${ }^{\S \S}$ & Before emergence & 0.025 & $23 \mathrm{Apr}$ \\
\hline & Glyphosate & & 1.42 & \\
\hline & Acetolchlor & Post application 1 & 2.53 & $28 \mathrm{Apr}$ \\
\hline & Atrazine & & 1.68 & \\
\hline & Topramezone & Post application 2 & 0.012 & 6 Jun \\
\hline & Glyphosate & & 1.08 & \\
\hline
\end{tabular}

Note. Chemical names: ${ }^{\dagger}$-chloro-4,6-bis(ethylamino)-s-triazine; ${ }^{\star} \mathrm{N}$-(phosphonomethyl) glycine; ${ }^{\S}$ Acetolchlor, 2-chloro-2'-ethyl-N-ethoxymethylacetanilide + Flumetsulam, N-(2,6-dfluorophenyl)-5-methyl-1,2,4-triazolo[1,5a]-pyrimidine-2-sulfonamide + Clopyralid, 3,6-dichloro-2 pyradinecarboxylic acid; "2-cholor-N-(2-ethyl-6methylphenyl) acetamide; ${ }^{*}$ (2-chloro-4-ethylamino)-6-(isopropylamino)-s-triazine; ${ }^{\dagger}\left[1 \mathrm{a}\left(\mathrm{S}^{*}\right), 3 \mathrm{a}(\mathrm{Z})\right]-( \pm)$-cyano(3-phenoxyphenyl) methyl-3-(2-chloro-3,3,3-trifluoro-1-propenyl)-2,2-dimethylcyclopropanecarboxylate; (4,5-dihydro-3-isoxazolyl)-2-methyl-4-(methylsulfonyl) phenyl] (5-hydroxy-1-methyl-1 $H$-pyrazol-4-yl) methanone; ${ }^{\S} \mathrm{N}$ '-(2-chloro-4-fluoro-5-(3-methyl-2,6-dioxo-4-(trifluoromethyl)-3,6-dihydro-1(2H)-pyrimidinyl) bezoyl-N-methylsulfamide.

\section{Results and Discussion}

\subsection{Precipitation}

Precipitation in 2012 was $35 \%$ ( $277 \mathrm{~mm}$ ) lower compared to average cumulative precipitation $(784 \mathrm{~mm})$ (Figure 1). The amount of daily precipitation started to decline shortly before UAN application at V3, and did not recover until the end of the season on 31 October. A 13-day difference was noted between harvest and harvest soil sample, and this period received $34 \%(135 \mathrm{~mm})$ of the total precipitation for the season. Cumulative precipitation in $2013(795 \mathrm{~mm})$ did not differ from the average cumulative precipitation $(784 \mathrm{~mm})$. Harvest and harvest soil sampling occurred on the same day. Cumulative daily precipitation in 2014 was $9 \%(74 \mathrm{~mm})$ higher than the average cumulative precipitation $(784 \mathrm{~mm})$. The daily precipitation events were relatively evenly distributed through the season. The number of days between harvest and post-harvest soil sampling were 13 and during this period there was $47 \mathrm{~mm}$ of precipitation. In 2015, daily cumulative precipitation was $962 \mathrm{~mm}$ and it was $23 \%(179 \mathrm{~mm})$ higher than the average daily cumulative from 2001 to 2011 . The time-period between harvest and harvest soil sample in 2015 was $43 \mathrm{~d}$, and there was $36 \mathrm{~mm}$ of rainfall during that time. 


\subsection{Air Temperature}

Average daily air temperatures from January 1 to December 31 for 2012, 2013, 2014 and 2015 are reported in Figure 2. In all four years, temperature was generally below freezing $\left(0{ }^{\circ} \mathrm{C}\right)$ from early-January to late-February. Relatively small temperature differences were observed among study years for the period of early-January to late-February except for 2012 and 2013 compared to 2014 and 2015. In 2012 and 2013, air temperature in this period fluctuated between $\pm 10{ }^{\circ} \mathrm{C}$ more than was noted in 2014 and 2015. In 2014 and 2015, the air temperature remained below $0{ }^{\circ} \mathrm{C}$ for longer intervals during that period. However, temperatures across years were similar for the time-period for which the corn crop was in the field. Temperatures started to rise above $10{ }^{\circ} \mathrm{C}$ from mid-March to late-May across years. Temperatures remained above $20{ }^{\circ} \mathrm{C}$ and below $30{ }^{\circ} \mathrm{C}$ from June to mid-October. This was followed by a decline in early-November which again ended up with several daily average temperatures below freezing in December.

\subsection{Grain Yields}

When corn yield data were analyzed using a single-factor ANOVA from 2012 to 2015, all the treatments had higher grain yields than the non-treated control at $\mathrm{P} \leq 0.05$ (data not presented). Subsequently, data were analyzed in the absence of non-treated control to determine any interactions using a three-factor ANOVA, and a significant interaction at $\mathrm{P} \leq 0.10$ among UAN application timing, rate, and nitrapyrin was noted (Table 3). A pre-emergence (PRE) application of UAN at $168 \mathrm{~kg} \mathrm{~N} \mathrm{ha}^{-1}$ with nitrapyrin resulted in the highest grain yield (8.6 $\left.\mathrm{Mg} \mathrm{ha}^{-1}\right)$ and was $11 \%$ greater than a PRE application of UAN at $168 \mathrm{~kg} \mathrm{~N} \mathrm{ha}^{-1}$ without nitrapyrin $\left(7.7 \mathrm{Mg} \mathrm{ha}^{-1}\right)$ (Figure 3). The UAN at $143{\mathrm{~kg} \mathrm{~N} h{ }^{-1}}^{-}$with nitrapyrin at $\mathrm{V} 3\left(8.2 \mathrm{Mg} \mathrm{ha}^{-1}\right)$ resulted in a $7 \%$ increase over UAN at $143 \mathrm{~kg} \mathrm{~N} \mathrm{ha}^{-1}$ without nitrapyrin at V3 $\left(7.6 \mathrm{Mg} \mathrm{ha}^{-1}\right)$. No significant difference was noted between yields of PRE UAN at 143 or $168 \mathrm{~kg} \mathrm{~N} \mathrm{ha}^{-1}$ with or without nitrapyrin.

These results are in contrast with those of Burzaco et al. (2013) who observed that both PRE and sidedress applications of nitrapyrin with UAN $\left(0,90\right.$ and $\left.180 \mathrm{~kg} \mathrm{~N} \mathrm{ha}^{-1}\right)$ did not have significant effects on corn grain yields compared to when nitrapyrin was not applied. The differences in results between the two studies may be due to the differences in tillage between the two studies since that study had conventional tillage and in this research the fields were maintained in no-till. In a subsequent meta-analysis of the research literature regarding grain yield response to spring-applied nitrapyrin, Burzaco et al. (2014) found that in 56\% of the research studies grain yield response was greater than zero. Similarly, Wolt (2004) in a synthesis of the literature found $62 \%$ positive grain yield responses to spring-applied nitrapyrin.

\subsection{Soil $N$}

Soil $\mathrm{NO}_{3}-\mathrm{N}$ and soil $\mathrm{NH}_{4}-\mathrm{N}$ concentrations at 0 to 22 and 23 to $46 \mathrm{~cm}$ depths for the $\mathrm{V} 3$ growth stage were analyzed using a single-factor one-way ANOVA because side-dress treatment applications had not occurred at that time (Table 4). Data were combined over years due to a lack of an interaction between years and treatments. At V3, all of the PRE applied treatments with or without nitrapyrin had greater $\mathrm{N}$ concentrations than the non-treated control $\left(14.2 \mathrm{mg} \mathrm{kg}^{-1}\right)$ for soil $\mathrm{NO}_{3}-\mathrm{N}$ from 0 to $22 \mathrm{~cm}$. All the treatments resulted in similar soil $\mathrm{NO}_{3}-\mathrm{N}$ concentrations from 0 to $22 \mathrm{~cm}$ at the V3 growth stage. At V3, only PRE applied UAN at $168 \mathrm{~kg} \mathrm{~N} \mathrm{ha}^{-1}$ without nitrapyrin $\left(25.5 \mathrm{mg} \mathrm{kg}^{-1}\right)$ resulted in significantly higher soil $\mathrm{NH}_{4}-\mathrm{N}$ concentration in the 0 to $22 \mathrm{~cm}$ depth compared to the non-treated control $\left(5.1 \mathrm{mg} \mathrm{kg}^{-1}\right)$. At the V3 growth stage in the 23 to $46 \mathrm{~cm}$ depth, PRE applied UAN at $168 \mathrm{~kg} \mathrm{~N} \mathrm{ha}^{-1}$ with nitrapyrin $\left(10.3 \mathrm{mg} \mathrm{kg}^{-1}\right)$ had higher soil $\mathrm{NO}_{3}-\mathrm{N}$ concentration compared to the non-treated control $\left(6.2 \mathrm{mg} \mathrm{kg}^{-1}\right)$. Soil test $\mathrm{N}$ concentrations at $\mathrm{V} 7$ were analyzed using a three-factor ANOVA at $\mathrm{P} \leq 0.10$. 

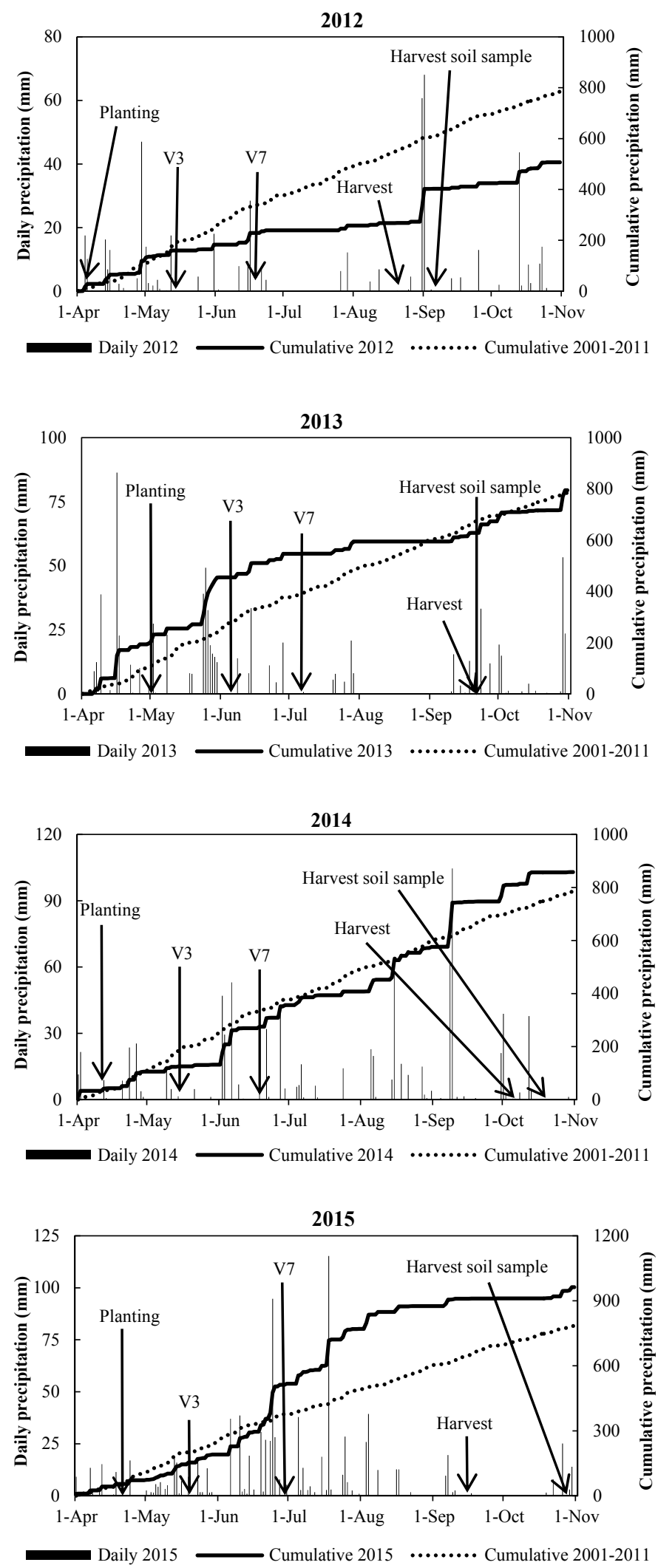

Figure 1. Precipitation history and timing of crop management practices for 2012, 2013, 2014 and 2015

Note. Bars represent daily precipitation; solid line represents cumulative precipitation over the season; and dotted-line represents cumulative precipitation from 2001 to 2011. V3 and V7 are corn growth stages (Ritchie et al., 1992). 

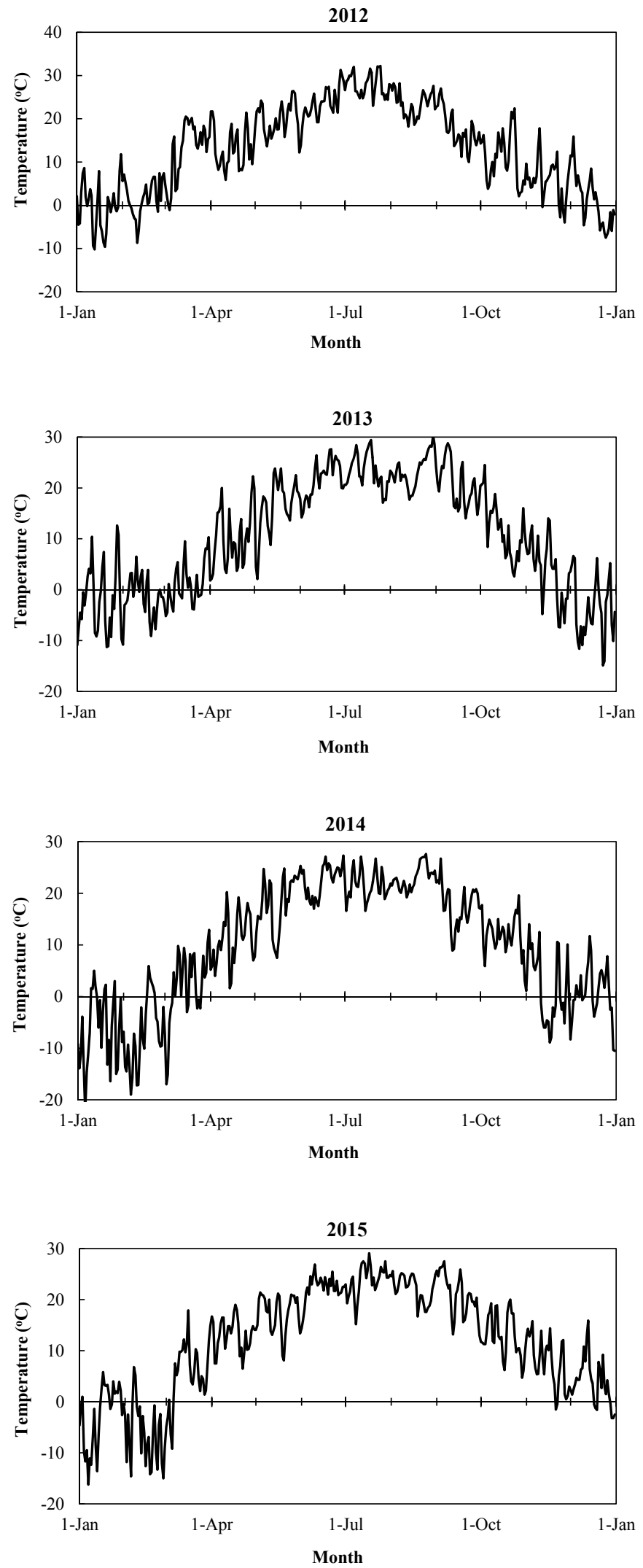

Figure 2. Daily average air temperature $\left({ }^{\circ} \mathrm{C}\right)$ for 2012, 2013, 2014 and 2015 
Table 3. Three-factor ANOVA table for selected corn production and quality variables

\begin{tabular}{|c|c|c|c|c|c|c|c|c|c|c|}
\hline \multirow{2}{*}{ Source } & \multirow{2}{*}{$\mathrm{df}$} & \multicolumn{2}{|c|}{ SPAD } & \multirow{2}{*}{$\begin{array}{l}\text { Plant } \\
\text { Population }\end{array}$} & \multicolumn{6}{|c|}{ Grain } \\
\hline & & V8 & VT & & Moisture & Test Wt. & Oil & Protein & Starch & Yield \\
\hline & & & & & & $-\operatorname{Pr}>F$ & & 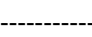 & ------ & - \\
\hline Year & 3 & $<.0001$ & $<.0001$ & 0.0229 & $<.0001$ & 0.0065 & $<.0001$ & $<.0001$ & $<.0001$ & $<.0001$ \\
\hline Year (Rep) & 4 & 0.1199 & 0.0036 & 0.0642 & 0.0069 & 0.5357 & 0.6273 & 0.2272 & 0.6617 & 0.9639 \\
\hline Timing & 1 & 0.0896 & 0.4302 & 0.4601 & 0.0104 & 0.1285 & 0.5837 & 0.2854 & 0.6112 & 0.6952 \\
\hline Year * Timing & 3 & 0.2751 & 0.9842 & 0.3061 & 0.5736 & 0.2678 & 0.5343 & 0.3676 & 0.6120 & 0.7704 \\
\hline Nitrapyrin & 1 & 0.5065 & 0.0258 & 0.3230 & 0.0607 & 0.5888 & 0.3453 & 0.1785 & 0.1161 & 0.0195 \\
\hline Year * Nitrapyrin & 3 & 0.0834 & 0.0341 & 0.2288 & 0.0231 & 0.5213 & 0.0822 & 0.7954 & 0.1341 & 0.0038 \\
\hline UAN rate & 1 & 0.4195 & 0.6107 & 0.5152 & 0.6818 & 0.9318 & 0.5630 & 0.4773 & 0.9201 & 0.4199 \\
\hline Year * UAN rate & 3 & 0.8410 & 0.9671 & 0.6636 & 0.1578 & 0.1505 & 0.9861 & 0.7983 & 0.8892 & 0.6126 \\
\hline Timing $*$ Nitrapyrin & 1 & 0.8236 & 0.5852 & 0.8374 & 0.4041 & 0.5881 & 0.7327 & 0.3351 & 0.2187 & 0.8473 \\
\hline Year $*$ Timing $*$ Nitrapyrin & 3 & 0.4786 & 0.4751 & 0.8920 & 0.9243 & 0.4357 & 0.9231 & 0.9886 & 0.9271 & 0.8657 \\
\hline Timing * UAN rate & 1 & 0.4087 & 0.1929 & 0.5088 & 0.9395 & 0.4779 & 0.9268 & 0.0321 & 0.3612 & 0.1857 \\
\hline Year $*$ Timing $*$ UAN rate & 3 & 0.1682 & 0.3082 & 0.1779 & 0.9839 & 0.8970 & 0.8822 & 0.6407 & 0.7871 & 0.2233 \\
\hline Nitrapyrin * UAN rate & 1 & 0.4482 & 0.8594 & 0.3145 & 0.1565 & 0.6214 & 0.9456 & 0.2789 & 0.4594 & 0.6059 \\
\hline Year * Nitrapyrin * UAN rate & 3 & 0.9339 & 0.1946 & 0.2853 & 0.1971 & 0.2190 & 0.7399 & 0.3948 & 0.5821 & 0.6709 \\
\hline Timing $*$ Nitrapyrin $*$ UAN rate & 1 & 0.2947 & 0.2331 & 0.1917 & 0.0530 & 0.0465 & 0.9427 & 0.6659 & 0.7599 & 0.0898 \\
\hline Year $*$ Timing $*$ Nitrapyrin $*$ UAN rate & 3 & 0.2155 & 0.1143 & 0.9858 & 0.1400 & 0.1887 & 0.9734 & 0.3268 & 0.8488 & 0.1585 \\
\hline
\end{tabular}

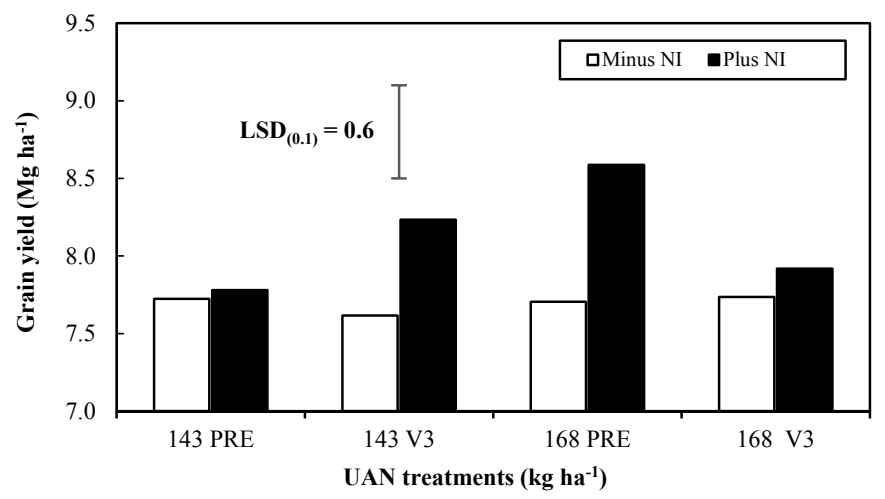

Figure 3. Corn grain yields were affected by UAN application timing (PRE or V3), application rate (143 or 168 $\mathrm{kg} \mathrm{ha}^{-1}$ ) and presence (Plus) or absence (Minus) of nitrification inhibitor (NI) (nitrapyrin). Data were combined over years (2012 to 2015). LSD, least significant difference at $P \leq 0.10$

There was no significant interaction between UAN application rates, timings and nitrapyrin for soil $\mathrm{NO}_{3}-\mathrm{N}$ concentration at the 0 to $22 \mathrm{~cm}$ depth at V7 (Table 3). However, UAN application timings and experimental years did have a significant interaction for soil $\mathrm{NH}_{4}-\mathrm{N}$ at the 0 to $22 \mathrm{~cm}$ depth at the $\mathrm{V} 7$ growth stage (Table 3). Soil $\mathrm{NH}_{4}-\mathrm{N}$ concentration in 2013 for $\mathrm{V} 3$ plants was greater $\left(39.3 \mathrm{mg} \mathrm{kg}^{-1}\right)$ than the PRE treatments at this growth stage (Table 5). At V7, soil $\mathrm{NH}_{4}-\mathrm{N}$ concentration in 2013 for PRE applied treatments was significantly greater $\left(27.9 \mathrm{mg} \mathrm{kg}^{-1}\right)$ than all the treatments applied PRE (Table 5). The V3 treatments generally resulted in greater soil $\mathrm{NH}_{4}-\mathrm{N}$ concentrations over PRE applied treatments (Table 5). An interaction between year and nitrapyrin was noted for soil $\mathrm{NO}_{3}-\mathrm{N}$ at 23 to $46 \mathrm{~cm}$ depth (Table 3). In 2014, V3 treatments in the absence of nitrapyrin had the greatest soil $\mathrm{NO}_{3}-\mathrm{N}\left(13.7 \mathrm{mg} \mathrm{kg}^{-1}\right)$ (Table 6). It was $54 \%\left(7.4 \mathrm{mg} \mathrm{kg}^{-1}\right)$ greater than the equivalent treatment with nitrapyrin.

Significant main effects and interactions for soil $\mathrm{N}$ concentration in the harvest soil sample were assessed using a three-factor ANOVA at $\mathrm{P} \leq 0.1$ (Table 3). UAN at $168 \mathrm{~kg} \mathrm{ha}^{-1}\left(16 \mathrm{mg} \mathrm{kg}^{-1}\right)$ increased soil $\mathrm{NO}_{3}-\mathrm{N}$ by $15 \%$ ( $3 \mathrm{mg}$ $\mathrm{kg}^{-1}$ ) compared to UAN at $143 \mathrm{~kg} \mathrm{ha}^{-1}$ at the 0 to $22 \mathrm{~cm}$ soil depth (Table 7). There was a year by UAN application timing interaction for soil $\mathrm{NH}_{4}-\mathrm{N}$ at the 0 to $22 \mathrm{~cm}$ depth. In 2012, soil $\mathrm{NH}_{4}-\mathrm{N}\left(13 \mathrm{mg} \mathrm{kg}^{-1}\right)$ 
concentration was the greatest at 0-20 cm depth with V3 applied UAN, and was greater than all PRE applied N treatments (Table 8). However, V3 applied treatments in 2015 had the lowest soil $\mathrm{NH}_{4}-\mathrm{N}$ concentration $(4 \mathrm{mg}$ $\mathrm{kg}^{-1}$ ). Except for 2015, V3 treatments generally resulted in higher soil $\mathrm{NH}_{4}-\mathrm{N}$ concentrations compared to PRE treatments. Soil $\mathrm{NO}_{3}-\mathrm{N}$ at a 23 to $46 \mathrm{~cm}$ depth, had a year $\times$ UAN application rate $\times$ timing $\times$ nitrapyrin interaction. In 2012, V3 UAN at $143 \mathrm{~kg} \mathrm{ha}^{-1}$ with nitrapyrin $\left(24 \mathrm{mg} \mathrm{kg}^{-1}\right)$ had a $50 \%\left(12 \mathrm{mg} \mathrm{kg}^{-1}\right)$ greater soil $\mathrm{NO}_{3}-\mathrm{N}$ concentration over the equivalent amount of UAN without nitrapyrin (Table 9). In contrast, V3 applied UAN at $168 \mathrm{~kg} \mathrm{ha}^{-1}$ in 2013 with nitrapyrin $\left(19 \mathrm{mg} \mathrm{kg}^{-1}\right)$ had a $13 \%\left(3 \mathrm{mg} \mathrm{kg}^{-1}\right)$ lower soil $\mathrm{NO}_{3}-\mathrm{N}$ concentration compared to UAN without nitrapyrin.

Table 4. Soil $\mathrm{NO}_{3}-\mathrm{N}$ and $\mathrm{NH}_{4}-\mathrm{N}$ concentrations from 0 to $22 \mathrm{~cm}$ depth at $\mathrm{V} 3$ growth stage for $\mathrm{N}$ application timing of pre-emergence (PRE) and V3, absence (Minus) or presence (Plus) of nitrification inhibitor (NI, nitrapyrin), and UAN rate (143 and $\left.168 \mathrm{~kg} \mathrm{ha}^{-1}\right)$. Data were averaged over years (2012-2015)

\begin{tabular}{|c|c|c|c|c|}
\hline \multirow{3}{*}{ UAN } & \multicolumn{4}{|c|}{$\mathrm{PRE}^{\dagger}$} \\
\hline & \multicolumn{2}{|c|}{$\mathrm{NO}_{3}-\mathrm{N}$} & \multicolumn{2}{|c|}{$\mathrm{NH}_{4}-\mathrm{N}$} \\
\hline & Minus NI & Plus NI & Minus NI & Plus NI \\
\hline -------------- kg ha"-1 ------------ & \multicolumn{4}{|c|}{ 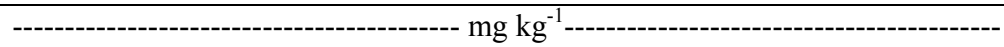 } \\
\hline Non-treated & \multicolumn{4}{|c|}{------------------ 14.2 ----------------- } \\
\hline 143 & 35.9 & 37.1 & 17.4 & 17.7 \\
\hline 168 & 45.2 & 34.3 & 25.5 & 19.3 \\
\hline $\operatorname{LSD}_{(0.01)} \ddagger$ & \multicolumn{2}{|c|}{------------------ 19.4 ----------------- } & \multicolumn{2}{|c|}{ 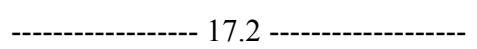 } \\
\hline Non-treated & \multicolumn{2}{|c|}{ 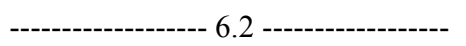 } & \multicolumn{2}{|c|}{------------------- 5.8 ------------------- } \\
\hline 143 & 10.2 & 9.3 & 7.0 & 5.4 \\
\hline 168 & 10.3 & 9.4 & 5.6 & 6.1 \\
\hline $\operatorname{LSD}_{(0.01)}$ & \multicolumn{2}{|c|}{-------------------- 4.1 ------------------- } & \multicolumn{2}{|c|}{------------------- NS ${ }^{\S}$-----------------' } \\
\hline
\end{tabular}

$\overline{\text { Note. }}{ }^{\dagger}$ Only one soil sample from $\mathrm{V} 3$ application timing plots at the $\mathrm{V} 3$ growth stage was taken because $\mathrm{V} 3$ application timing treatments were applied after soil sampling. This one sample was assumed to represent all the $\mathrm{V} 3$ application timing plots. Soil $\mathrm{NO}_{3}-\mathrm{N}$ and $\mathrm{NH}_{4}-\mathrm{N}$ from 0 to $22 \mathrm{~cm}$ depth for $\mathrm{V} 3$ application timing plots were 13.9 and $6.0 \mathrm{mg} \mathrm{kg}^{-1}$, respectively. Soil $\mathrm{NO}_{3}-\mathrm{N}$ and $\mathrm{NH}_{4}-\mathrm{N}$ from 23 to $46 \mathrm{~cm}$ depth for $\mathrm{V} 3$ application timing plots were 4.6 and $5.6 \mathrm{mg} \mathrm{kg}^{-1}$, respectively; ${ }^{\sharp}$ Least significant difference at $P \leq 0.01 ;{ }^{\S}$ Non-significant.

Table 5. Soil $\mathrm{NH}_{4}-\mathrm{N}$ concentrations from 0 to $22 \mathrm{~cm}$ depth at $\mathrm{V} 7 \mathrm{corn}$ growth stage for application timing (PRE and V3) and years (2012-2015)

\begin{tabular}{llc}
\hline Year & PRE & V3 \\
\hline & & -12 \\
2013 & 15.8 & 31.6 \\
2014 & 27.9 & 39.3 \\
2015 & 19.0 & 19.0 \\
$\operatorname{LSD}_{(0.1)}{ }^{\dagger}$ & 12.3 & 14.3 \\
\hline
\end{tabular}

Note. ${ }^{\dagger}$ Least significant difference at $P \leq 0.10$.

UAN 143 at $\mathrm{kg} \mathrm{ha}^{-1}$ without nitrapyrin at $\mathrm{V} 3$ had soil $\mathrm{NO}_{3}-\mathrm{N}$ that was $22 \%$ greater compared to the equivalent treatment with nitrapyrin. This was in contrast to what was observed in the equivalent treatment in 2012. This result indicates a possible difference in plant $\mathrm{N}$ uptake between years. During a drought year (2012), the highest soil $\mathrm{NO}_{3}-\mathrm{N}$ concentrations were observed. All the treatments in 2012 resulted in significantly greater soil $\mathrm{NO}_{3}-\mathrm{N}$ concentrations compared to their respective treatments in 2013, 2014 and 2015. The lowest soil $\mathrm{NO}_{3}-\mathrm{N}$ concentrations were observed in 2015, and were similar to 2014 . 
Table 6. Soil $\mathrm{NO}_{3}-\mathrm{N}$ from 23 to $46 \mathrm{~cm}$ depth at $\mathrm{V} 7$ for application timing (PRE and V3), absence (Minus) or presence (Plus) of nitrification inhibitor (NI, nitrapyrin) and years (2012-2015)

\begin{tabular}{|c|c|c|c|c|}
\hline \multirow{2}{*}{ Year } & \multicolumn{2}{|c|}{ PRE } & \multicolumn{2}{|c|}{ V3 } \\
\hline & Minus NI & Plus NI & Minus NI & Plus NI \\
\hline & \multicolumn{4}{|c|}{ 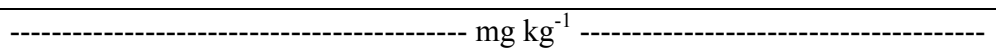 } \\
\hline 2012 & 2.3 & 3.7 & 1.9 & 2.3 \\
\hline 2013 & 9.5 & 9.8 & 7.6 & 8.7 \\
\hline 2014 & 8.5 & 10.0 & 13.7 & 6.3 \\
\hline 2015 & 6.6 & 5.8 & 3.1 & 4.2 \\
\hline $\operatorname{LSD}_{(0.10)}^{\dagger}$ & \multicolumn{4}{|c|}{ - 2.5 - } \\
\hline
\end{tabular}

Note. ${ }^{\dagger}$ Least significant difference at $P \leq 0.10$.

Table 7. Soil $\mathrm{NO}_{3}-\mathrm{N}$ from 0 to $22 \mathrm{~cm}$ depth at harvest for UAN application rates $\left(143\right.$ and $\left.168 \mathrm{~kg} \mathrm{ha}^{-1}\right)$. Data were averaged across the years (2012-2015)

\begin{tabular}{|c|c|}
\hline UAN & $\mathrm{NO}_{3}-\mathrm{N}$ \\
\hline - & - \\
\hline 143 & 13.7 \\
\hline 168 & 16.2 \\
\hline $\operatorname{LSD}_{(0.10)}^{\dagger}$ & ---------------------- 2.4 ------------------- \\
\hline
\end{tabular}

Note. ${ }^{\dagger}$ Least significant difference at $P \leq 0.10$.

Table 8. Soil $\mathrm{NH}_{4}-\mathrm{N}$ from 0 to $22 \mathrm{~cm}$ depth at harvest for application timing (PRE and V3) and years (2012-2015)

\begin{tabular}{|c|c|c|}
\hline \multirow{2}{*}{ Year } & \multicolumn{2}{|c|}{$\mathrm{NH}_{4}-\mathrm{N}$} \\
\hline & PRE & V3 \\
\hline & \multicolumn{2}{|c|}{ 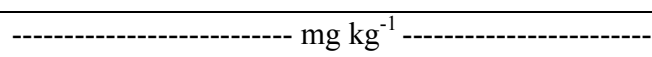 } \\
\hline 2012 & 4.2 & 13.3 \\
\hline 2013 & 4.9 & 5.9 \\
\hline 2014 & 4.6 & 6.4 \\
\hline 2015 & 4.3 & 3.8 \\
\hline $\operatorname{LSD}_{(0.10)}^{\dagger}$ & \multicolumn{2}{|c|}{ 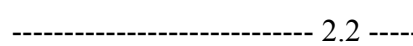 } \\
\hline
\end{tabular}

Note. ${ }^{\dagger}$ Least significant difference at $P \leq 0.10$.

Table 9. Soil $\mathrm{NO}_{3}-\mathrm{N}$ from 23 to $46 \mathrm{~cm}$ depth at harvest for application rates (UAN $143 \mathrm{~kg} \mathrm{ha}^{-1}$ and UAN $168 \mathrm{~kg}$ $\mathrm{ha}^{-1}$ ), application timing (PRE and V3), absence (Minus) or presence (Plus) of nitrification inhibitor (NI, nitrapyrin) and years (2012-2015)

\begin{tabular}{|c|c|c|c|c|c|c|c|c|}
\hline \multirow{3}{*}{ Year } & \multicolumn{4}{|c|}{ UAN $143 \mathrm{~kg} \mathrm{ha}^{-1}$} & \multicolumn{4}{|c|}{ UAN $168 \mathrm{~kg} \mathrm{ha}^{-1}$} \\
\hline & \multicolumn{2}{|c|}{ PRE } & \multicolumn{2}{|c|}{ V3 } & \multicolumn{2}{|c|}{ PRE } & \multicolumn{2}{|c|}{ V3 } \\
\hline & Minus NI & Plus NI & Minus NI & Plus NI & Minus NI & Plus NI & Minus NI & Plus NI \\
\hline & $\begin{array}{ll}----- \\
\end{array}$ & -------- & $\begin{array}{ll}----- \\
---1\end{array}$ & --------- & - & - & 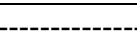 & 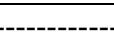 \\
\hline 2012 & 12.3 & 11.6 & 11.9 & 23.9 & 12.5 & 11.2 & 22.3 & 19.4 \\
\hline 2013 & 4.7 & 4.7 & 9.1 & 7.1 & 5.7 & 5.2 & 7.3 & 7.3 \\
\hline 2014 & 1.7 & 3.3 & 1.8 & 1.9 & 1.7 & 2.0 & 2.1 & 3.7 \\
\hline 2015 & 1.5 & 1.3 & 1.6 & 1.2 & 1.8 & 1.2 & 1.4 & 1.7 \\
\hline
\end{tabular}

Note. ${ }^{\dagger}$ Least significant difference at $P \leq 0.10$. 


\subsection{Leaf SPAD Meter Readings}

An interaction for leaf SPAD meter readings between year and nitrapyrin at V8 and VT growth stages occurred (Table 3). SPAD readings at V8 and VT in 2015 were the lowest (33 to 43 SPAD units) among all years regardless of the presence or absence of nitrapyrin (Table 10). The highest SPAD reading was noted at VT in 2014 with or without nitrapyrin (58 SPAD units). Nitrapyrin in 2015 at V8 (43 SPAD units) and VT (38 SPAD units) had higher SPAD readings (4 and 5 SPAD units) compared to the absence of nitrapyrin. In 2012 and 2014, SPAD readings at VT increased over SPAD readings at V8, while in 2013 and 2015 SPAD readings decreased at VT compared to V8 regardless of presence or absence of nitrapyrin.

Table 10. SPAD meter readings in the absence (minus) or presence (plus) of nitrification inhibitor (NI, nitrapyrin) measured at the V8 and VT growth stages for the years of 2012 to 2015

\begin{tabular}{|c|c|c|c|c|}
\hline \multirow{2}{*}{ Year } & \multicolumn{2}{|c|}{ V8 } & \multicolumn{2}{|c|}{ VT } \\
\hline & Minus NI & Plus NI & Minus NI & Plus NI \\
\hline & \multicolumn{4}{|c|}{ 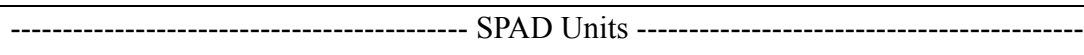 } \\
\hline 2012 & 45.2 & 45.0 & 47.4 & 47.7 \\
\hline 2013 & 56.4 & 55.2 & 44.3 & 44.8 \\
\hline 2014 & 51.6 & 51.4 & 58.0 & 58.3 \\
\hline 2015 & 39.4 & 42.8 & 33.1 & 38.1 \\
\hline $\operatorname{LSD}_{(0.10)}^{\dagger}$ & \multicolumn{2}{|c|}{ 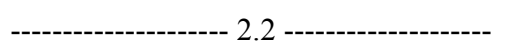 } & \multicolumn{2}{|c|}{ - } \\
\hline
\end{tabular}

Note. ${ }^{\dagger}$ Least significant difference at $P \leq 0.10$.

All these differences in SPAD readings may have been affected by differences in daily and total precipitation amounts and distribution of precipitation events over the growing seasons. For example, 2012 was relatively a dry year with low daily precipitation events that may have reduced SPAD readings potentially due to low moisture content of soil which limits $\mathrm{NO}_{3}-\mathrm{N}$ uptake by plants. Furthermore, 2015 was the wettest year of study and it received high precipitation events over the course of the season which may have increased $\mathrm{N}$ losses due to leaching and denitrification mechanisms. Nitrapyrin in 2015 at both V8 and VT stages had a significant effect compared to when nitrapyrin was not applied because nitrification inhibitors are often more effective where risk of $\mathrm{N}$ losses due to excessive wet soil conditions is high (Randall et al., 2003).

\subsection{Grain Moisture, Test Weight, and Protein Content}

Grain moisture had an interaction for UAN application rates, application timings and nitrapyrin at $\mathrm{P} \leq 0.1$ (Table 3). UAN at $143 \mathrm{~kg} \mathrm{ha}^{-1}$ without nitrapyrin at $\mathrm{V} 3\left(197 \mathrm{~g} \mathrm{~kg}^{-1}\right)$ had the highest grain moisture content, and was greater than all the other treatments (Table 11). The UAN at $168 \mathrm{~kg} \mathrm{ha}^{-1}$ with nitrapyrin applied PRE $\left(180 \mathrm{~g} \mathrm{~kg}^{-1}\right)$ resulted in the lowest grain moisture content, and was significantly lower $\left(9 \mathrm{~g} \mathrm{~kg}^{-1}\right)$ than an equivalent treatment at V3. Grain moisture content was generally lower in treatments with nitrapyrin compared to treatment without nitrapyrin.

Table 11. Grain moisture and test weight in the absence (minus) and or presence (plus) of nitrification inhibitor (NI, nitrapyrin) for application timings (PRE and V3) and UAN rates (143 and $168 \mathrm{~kg} \mathrm{ha}^{-1}$ ), and grain protein concentration for application timings and UAN rates. Data were combined over years (2012-2015)

\begin{tabular}{|c|c|c|c|c|c|}
\hline \multirow{2}{*}{ UAN } & \multicolumn{2}{|l|}{ Moisture } & \multicolumn{2}{|c|}{ Test Weight } & \multirow{2}{*}{ Protein } \\
\hline & Minus NI & Plus NI & Minus NI & Plus NI & \\
\hline ----------- kg ha ${ }^{-1}$----------- & \multicolumn{2}{|c|}{--------- g kg $^{-1}$} & \multicolumn{2}{|c|}{--------- kg m } & --- $\mathrm{g} \mathrm{kg}^{-1}---$ \\
\hline 143 PRE & 184 & 183 & 747 & 733 & 83 \\
\hline $143 \mathrm{~V} 3$ & 197 & 182 & 728 & 735 & 85 \\
\hline $168 \mathrm{PRE}$ & 184 & 180 & 735 & 740 & 85 \\
\hline $168 \mathrm{~V} 3$ & 188 & 189 & 737 & 731 & 84 \\
\hline $\operatorname{LSD}_{(0.1)}{ }^{\dagger}$ & \multicolumn{2}{|c|}{----------------- 8 ----------------- } & \multicolumn{2}{|c|}{----------------- 14 ---------------- } & 2 \\
\hline
\end{tabular}

Note. ${ }^{\dagger}$ Least significant difference at $P \leq 0.10$. 
There was an interaction between UAN application rates, application timings and nitrapyrin at $\mathrm{P} \leq 0.1$ for grain test weight (Table 3). UAN at $143 \mathrm{~kg} \mathrm{ha}^{-1}$ without nitrapyrin at the PRE timing increased grain test weight $2 \%$ $\left(14 \mathrm{~kg} \mathrm{~m}^{-3}\right)$ compared to the equivalent treatment with nitrapyrin (Table 11). It was also $3 \%$ greater $\left(19 \mathrm{~kg} \mathrm{~m}^{-3}\right)$ than its equivalent treatment applied at V3 $\left(728 \mathrm{~kg} \mathrm{~m}^{-3}\right)$. Corn hybrids used in this study each year were not the same. This may be one possible reason the grain test weight was different among treatments.

There was an interaction between UAN application rates and application timings for grain protein (Table 3). PRE UAN at $143 \mathrm{~kg} \mathrm{ha}^{-1}$ had the lowest grain protein concentration $\left(83 \mathrm{~g} \mathrm{~kg}^{-1}\right)$ (Table 11). UAN at $143 \mathrm{~kg} \mathrm{ha}^{-1}$ applied at PRE and UAN at $168 \mathrm{~kg} \mathrm{ha}^{-1}$ applied at V3 both resulted in similar grain protein concentrations $\left(85 \mathrm{~g} \mathrm{~kg}^{-1}\right)$, and were greater than V3 applied UAN at $143 \mathrm{~kg} \mathrm{ha}^{-1}$. Grain protein results are more likely a representation of leaf SPAD meter readings because both SPAD meter readings and grain protein concentration had similar trends. There was no difference among treatments for grain oil concentration, starch concentration or plant population (data not presented).

Since these treatments were assessed over four growing seasons, climatic variability within growing seasons affects the observed results especially the extreme weather events that occurred during this research. For example, 2015 was relatively the wettest season with a majority of precipitation of the season occurring in a short interval of time, while 2012 was one of the driest seasons on record (USDM, 2015). Hence, the impact of applying nitrapyrin with UAN may have been more positive due to the excess soil moisture.

\section{Conclusions}

An application of UAN at $143 \mathrm{~kg} \mathrm{ha}^{-1}$ with nitrapyrin at V3 had the highest grain yield $\left(8.6 \mathrm{Mg} \mathrm{ha}^{-1}\right)$, followed by $7.7 \mathrm{Mg} \mathrm{ha}^{-1}$ yield with UAN at $168 \mathrm{~kg} \mathrm{ha}^{-1}$ with nitrapyrin applied PRE. Soil $\mathrm{NO}_{3}-\mathrm{N}$ and $\mathrm{NH}_{4}-\mathrm{N}$ concentrations were generally affected by UAN application rates and timings, and relatively less by the application of nitrapyrin. In the wettest year (2015), nitrapyrin increased leaf SPAD meter readings which were likely related to grain protein concentrations. Overall, the presence of nitrapyrin had lower overall grain moisture levels. Plant population, grain oil and starch concentrations were not affected by any of the treatments in the experiment. The highest corn yields were obtained with UAN at $143 \mathrm{~kg} \mathrm{ha}^{-1}$ with nitrapyrin at V3 and UAN at $168 \mathrm{~kg} \mathrm{ha}^{-1}$ with nitrapyrin applied at PRE. Based on these findings, a side-dress application of a lower rate of UAN with nitrapyrin at $\mathrm{V} 3$ may be effective when the risk of $\mathrm{N}$ losses during the growing season due to unfavorable precipitation events and other environmental variables are high. A PRE application of UAN with nitrapyrin was beneficial, but not as effective as applying the nitrapyrin with the side-dress application. However, further research into investigating the cost-benefit ratio of using nitrapyrin with UAN on corn production would be important to assist growers in making decisions on the best timings and rates of UAN in combination with nitrapyrin to utilize in poorly-drained soils.

\section{References}

Anderson, S. H., Gantzer, C. J., \& Brown, J. R. (1990). Soil physical properties after 100 years of continuous cultivation. J. Soil Water Conserv., 45, 117-121.

Burzaco, J. P., Ciampitti, I. A., \& Vyn, T. J. (2014). Nitrapyrin impacts on maize yield and nitrogen use-efficiency with spring-applied nitrogen: Field studies vs. meta-analysis comparison. Agron. J., 106, 753-760. https://doi.org/10.2134/agronj2013.0043

Burzaco, J. P., Smith, D. R., \& Vyn, T. J. (2013). Nitrous oxide emissions in Midwest US maize production vary widely with band-injected $\mathrm{N}$ fertilizer rates, timing and nitrapyrin presence. Environ. Res. Lett., 8(3), 1-11. https://doi.org/10.1088/1748-9326/8/3/035031

Halvorson, A. D., \& del Grosso, S. J. (2012). Nitrogen source and placement effects on soil nitrous oxide emissions from no-till corn. J. Environ. Qual., 41(5), 1349-1360. https://doi.org/10.2134/jeq2012.0129

Halvorson, A. D., del Grosso, S. J., \& Alluvione, F. (2010). Nitrogen source effects on nitrous oxide emissions from irrigated no-till corn. J. Environ. Qual., 39(5), 1554. https://doi.org/10.2134/jeq2010.0041

Jung, W. K., Kitchen, N. R., Sudduth, K. A., \& Anderson, S. H. (2006). Spatial characteristics of claypan soil properties in an agricultural field. Soil Sci. Soc. Am. J., 70(4), 1387-1397. https://doi.org/10.2136/ sssaj2005.0273

Maharjan, B., Ferguson, R. B., \& Slater, G. P. (2017). Irrigated corn productivity as influenced by nitrogen source, rate, and climatic conditions. Agron. J., 109, 1-9. https://doi.org/10.2134/agronj2017.04.0209

Millar, N., Robertson, G. P., Grace, P. R., Gehl, R. J., \& Hoben, J. P. (2010). Nitrogen fertilizer management for nitrous oxide $\left(\mathrm{N}_{2} \mathrm{O}\right)$ mitigation in intensive corn (Maize) production: An emissions reduction protocol for 
US Midwest agriculture. Mitig. Adapt. Strateg. Glob. Change, 15(2), 185-204. https://doi.org/10.1007/ s11027-010-9212-7

Myers, D. B., Kitchen, N. R., Sudduth, K. A., Sharp, R. E., \& Miles, R. J. (2007). Soybean root distribution related to claypan soil properties and apparent soil electrical conductivity. Crop Sci., 47(4), 1498-1509. https://doi.org/10.2135/cropsci2006.07.0460

Nathan, M., Stecker, J., \& Sun, Y. (2006). Soil testing in Missouri: A guide for conducting soil test in Missouri. Mo. Coop Ext Ser Pub EC923 Univ Mo. Columbia MO. Retrieved October 8, 2016, from http://soilplantlab.missouri.edu/soil/ec923.pdf

Randall, G. W., \& Sawyer, J. E. (2008). Nitrogen application timing, forms, and additives. In Final Report: Gulf Hypoxia and Local Water Quality Concerns Workshop (pp. 73-85). Upper Mississippi River Sub-basin Hypoxia Nutrient Committee, St. Joseph, MI: American Society of Agricultural and Biological Engineers.

Randall, G. W., \& Vetch, J. A. (2003). Corn production on a subsurface-drain Mollisol as affected by time of nitrogen application and nitrapyrin. Agron. J., 95, 1213-1219. https://doi.org/10.2134/agronj2003.1213

Ritchie, S. W., Hanway, J. J., \& Benson, G. O. (1992). How a corn plant develops. Special Report No. 48. Iowa State University of Science and Technology, Cooperative Extension Service, Ames, IA.

SAS Institute. (2013). Base 9.4 Procedures Guide. SAS Institute Inc., Cary, NC.

United States Drought Monitor. (2015). U.S. drought monitor map archive. The National Drought Mitigation Center, Lincoln, NE, USA. Retrieved June 5, 2015, from http://droughtmonitor.unl.edu/MapsAndData/ MapArchive.aspx

University of Missouri Extension. (2016). Daily and Hourly Weather Query. Missouri Hist. Agric. Weather Database. Retrieved July 6, 2017, from http://agebb.missouri.edu/weather/history

Wolt, J. D. (2004). A meta-evaluation of nitrapyrin agronomic and environmental effectiveness with emphasis on corn production in the Midwestern USA. Nutr. Cycl. Agroecosystems, 69(1), 23-41. https://doi.org/10.1023/ B:FRES.0000025287.52565.99

\section{Copyrights}

Copyright for this article is retained by the author(s), with first publication rights granted to the journal.

This is an open-access article distributed under the terms and conditions of the Creative Commons Attribution license (http://creativecommons.org/licenses/by/4.0/). 